\title{
SOIL PROPERTIES IN DIFFERENT YEARS OF CULTIVATION ABANDONMENT IN THE MIDSTREAM AND DOWNSTREAM OF SHIYANG RIVER AREA
}

\author{
WANG, L. D. ${ }^{1,2,3^{*}}-$ GuO, C. X. ${ }^{1,2,3}-$ XU, B. Y. ${ }^{1,2,3}-$ WU, H. ${ }^{1,2,3}-$ WANG, F. L. ${ }^{1,2,3}-$ LI, X. J. ${ }^{1,2,3}$ \\ ${ }^{1}$ Gansu Desert Control Research Institute, Lanzhou 730070, China \\ ${ }^{2}$ Gansu Hexi Corridor Forest Ecosystem National Research Station, Wuwei 733000, China \\ ${ }^{3}$ State Key Laboratory Breeding Base of Desertification and Aeolian Sand Disaster Combating, \\ Wuwei 733000, China \\ (e-mail:wld69@tom.com,guochunxiu0414@163.com,68428666@qq.com, \\ wuhao4832@163.com,466961776@qq.com,124213741@qq.com) \\ ${ }^{*}$ Corresponding author \\ e-mail:wld69@tom.com \\ (Received 27 $7^{\text {th }}$ Feb 2019; accepted $3^{\text {rd }}$ May 2019)
}

\begin{abstract}
To understand changes of soil properties in different years of cultivation abandonment in the midstream and downstream of Shiyang River area, soil physicochemical characteristics, microbial population, soil microbial biomass, relationships between them and comprehensive evaluation of soil fertility quality were analyzed. The results showed that soil $\mathrm{pH}$ increased slightly, soil water content, sand content, the number of bacteria , the number of actinomycetes and SMBN (soil microbial biomass nitrogen) decreased then increased, soil organic carbon, total potassium, Quick-available K, Quickavailable P, SMBC (soil microbial biomass carbon), SMBP (soil microbial biomass phosphorus) and SMBC/SMBN increased then decreased, total nitrogen increased then decreased and tended to be stable, total phosphorus and the number of fungi decreased then increased and decreased finally, and different abandoned years had different significant difference. From the correlation analysis and principal component analysis (PCA), there were close correlations among the soil physical characteristics, soil chemical characteristics and the number of soil microbes, soil microbial biomass. The key factors determining the soil quality were the soil $\mathrm{pH}$, sand content, soil water content, soil water content, total nitrogen, Quick-available K, the number of fungi, SMBC and SMBN. The results that the effects of 4a on the soil during restoration were better for soil improvement than the other abandoned years, making the abandoned years of $4 \mathrm{a}$ more critical for use in the ecological restoration and control of the midstream and downstream of Shiyang River area.
\end{abstract}

Keywords: soil microbial characteristics, soil physicochemical characteristics, soil fertility, midstream and downstream of Shiyang river, years of abandoned cultivated lands

\section{Introduction}

Shiyang River is a typical inland river in the arid regions of northwestern China. Its downstream Minqin area was once a natural oasis with plenty water and rush grass (Feng, 1963). However, in recent decades, with the continuous expansion of the population and economic scale of midstream area of Shiyang River, especially the expansion of artificial oases, the downstream surface water resources are decreasing day by day, the groundwater is seriously over-exploited, the degree of mineralization is rising, natural vegetation is subject to serious disturbance and damage, a series of ecological problems such as desertification and salinization have been intensified (Zhang et al., 2016; Chang et al., 2016), causing large-scale land to be abandoned and uncultivated which deteriorates into secondary grassland. If these secondary grasslands 
are not properly protected, degradation will speed up, wind erosion and desertification will occur with emergence of new source of sand and dust, forming a vicious circle and seriously damaging soil ecosystem of the secondary grassland in the middle and lower reaches of Shiyang River (Chai et al., 2015). Therefore, how to properly protect and restore secondary grassland in abandoned oasis area in the middle and lower reaches of Shiyang River is an ecological problem that needs to be settled urgently.

Soil serves as the carrier of many ecological processes in ecosystems and the substrate for plant growth (Hu and Guo, 2012). Its physicochemical properties and biological properties are key indicators reflecting restoration degree of soil ecosystems (Yuan et al., 2012). Studies have shown that soil microbes in soil ecosystems mainly participate in material circulation and energy flow by decomposing animal and plant residues, which serve as supply source and reservoir pool of soil nutrients, affecting vegetation succession and soil quality (Kardol et al., 2007). The amount of soil microbes is used to study and evaluate soil microbial regulation functions, which can reflect the effects of various soil factors on soil microbes and its effects on plant growth and soil fertility, and exert certain regulation on the whole ecosystem (Harris, 2003). Soil microbial biomass constitutes living soil organic matter, which is a sign of soil activity and one of the early warning indicators of soil ecosystem changes (Singh et al., 2014). At present, research on the evolution of soil properties mainly focuses on physicochemical properties of soil (Zhao et al., 2012), while there are few reports on the evolution of soil properties in the Shiyang River Basin. In view of this, this paper studies change characteristics of physical properties, chemical properties and microbial properties of secondary grassland with different abandoned years in different middle and lower reaches of Shiyang River, discusses the relationship between them and makes comprehensive evaluation of soil quality in this area, with a view to making in-depth exploration into evolution process of soil properties in Shiyang River Basin, and providing a theoretical basis for ecological restoration and management in the area.

\section{Materials and methods}

\section{Overview of the study area}

The test site was selected in Huanghui Village and Ziyun Village, Xiqu Town, north of Minqin County, Gansu Province. The geographical coordinates are located at east longitude $103^{\circ} 07^{\prime} 50^{\prime \prime} \sim 103^{\circ} 37^{\prime} 56^{\prime \prime}$ and north latitude $39^{\circ} 01^{\prime} 30^{\prime \prime}-39^{\circ} 03^{\prime} 28^{\prime \prime}$. The altitude is $1297 \sim 1306 \mathrm{~m}$, the annual average temperature is $7.4^{\circ} \mathrm{C}$, the average annual precipitation is $110 \mathrm{~mm}$ which is mainly concentrated in July September, the annual average evaporation is $2644 \mathrm{~mm}$, the annual sunshine hours are $2832.1 \mathrm{~h}$, and the annual average wind speed is $2.3 \mathrm{~m} / \mathrm{s}$. The soil type is gray brown desert soil. The main shrub plants in the plot include Nitraria schoberi, Kalidium foliatum, Lycium chinense, Nitraria sibirica, Reaumuria songarica, etc. The herbaceous plants include Convolvulus arvensis, Chenopodium album, Halogeton arachnoideus, Suaeda glauca, Peganum harmala, Salsola ikonnikovii, etc. (Chai et al., 2015).

\section{Sample site setting and soil sample collection}

In September 2012, interview and investigation was conducted in the forestry department and local residents of Minqin County to accurately grasp abandoned time in the middle and lower reaches of Shiyang River. By using method of space replacement 
time, sections with uniform plant growth, small changes in microtopography, and without topography change owing to natural factors or soil material redistribution caused by human factors were selected as test area. While ensuring that soil parent materials of the sample site was consistent, 9 wastelands where crops have been planted $1,2,3,4,5,8$, and 15. 24 and 31a with an area of $1 \mathrm{hm} 2$ was selected as sample site (see Table 1).

Table 1. Basic condition of sample sites

\begin{tabular}{|c|c|c|c|c|c|}
\hline $\begin{array}{c}\text { Abandoned } \\
\text { years(a) }\end{array}$ & $\begin{array}{c}\text { Altitude } \\
(\mathbf{m})\end{array}$ & \begin{tabular}{|c|}
$\begin{array}{c}\text { Longitude/ } \\
\text { Latitude }\end{array}$ \\
\end{tabular} & Dominant plants species & Accompanying species & $\begin{array}{c}\text { (Plant type before } \\
\text { abandonment) }\end{array}$ \\
\hline $1 \mathrm{a}$ & 1304 & $\begin{array}{l}\mathrm{E} 103^{\circ} 36^{\prime} 03 \\
\mathrm{~N} 39^{\circ} 03^{\prime} 28^{\prime \prime}\end{array}$ & $\begin{array}{l}\text { Chenopodium album, } \\
\text { Convolvulus arvensis, } \\
\text { Echinopilon divaricatum, } \\
\text { Peganum harmala }\end{array}$ & $\begin{array}{l}\text { P. nigellastrum, Chloris virgata, } \\
\text { Corispermum hyssopifolium, } \\
\text { Polygonumaviculare et al }\end{array}$ & The autumn crops \\
\hline $2 \mathrm{a}$ & 1303 & $\begin{array}{l}\mathrm{E} 103^{\circ} 36^{\prime} 09^{\prime \prime} \\
\mathrm{N} 39^{\circ} 03^{\prime} 25^{\prime \prime}\end{array}$ & \begin{tabular}{|c|} 
Sonchus oleraceus, $P$. \\
nigellastrum, Halogeton \\
arachnoideus, Lepidium lotifolium \\
\end{tabular} & $\begin{array}{c}\text { Atriplex sibirica, Chenopodium album, } \\
\text { Chloris virgata, Euphorbia pekinensis } \\
\text { et al. }\end{array}$ & The autumn crops \\
\hline $3 a$ & 1297 & $\begin{array}{l}\mathrm{E} 103^{\circ} 36^{\prime} 09^{\prime \prime} \\
\mathrm{N} 39^{\circ} 02^{\prime} 36^{\prime \prime}\end{array}$ & \begin{tabular}{|c|} 
P. nigellastrum, Halogeton \\
arachnoideus, Lepidium \\
lotifolium, Acroptilon repens \\
\end{tabular} & $\begin{array}{c}\text { Limoniumau-reum, Phragmites } \\
\text { australis, Peganum harmala, Eragrostis } \\
\text { pilosa et al. }\end{array}$ & The autumn crops \\
\hline $4 a$ & 1305 & $\begin{array}{l}\mathrm{E} 103^{\circ} 36^{\prime} 13^{\prime \prime} \\
\mathrm{N} 39^{\circ} 02^{\prime} 34^{\prime \prime}\end{array}$ & $\begin{array}{c}\text { Peganum harmala, Acroptilon } \\
\text { repens, } P \text {. nigellastrum, Suaeda } \\
\text { glauca }\end{array}$ & $\begin{array}{l}\text { Phragmites australis, Chloris virgata, } \\
\text { Halogeton arachnoideus et al. }\end{array}$ & The autumn crops \\
\hline 5 & 1304 & $\begin{array}{l}\mathrm{E} 103^{\circ} 35^{\prime} 58^{\prime \prime} \\
\mathrm{N} 39^{\circ} 02^{\prime} 9^{\prime \prime}\end{array}$ & $\begin{array}{c}\text { Lycium ruthenicum, Halogeton } \\
\text { arachnoideus, Lepidium } \\
\text { lotifolium, Peganum harmala } \\
\end{array}$ & $\begin{array}{l}\text { Cardaria draba, Clematis florida, } P . \\
\text { nigellastrum, Chloris virgata et al. }\end{array}$ & The autumn crops \\
\hline $8 \mathrm{a}$ & 1304 & $\begin{array}{l}\mathrm{E} 103^{\circ} 07^{\prime} 54^{\prime \prime} \\
\mathrm{N} 39^{\circ} 02^{\prime} 54^{\prime \prime}\end{array}$ & $\begin{array}{c}\text { Lycium ruthenicum, Halogeton } \\
\text { arachnoideus, Peganum harmala, } \\
\text { P. nigellastrum }\end{array}$ & $\begin{array}{c}\text { Phragmites australis, Acroptilon } \\
\text { repens, Limoniumau-reum, } \\
\text { Achnatherum splendens et al. }\end{array}$ & The autumn crops \\
\hline $15 \mathrm{a}$ & 1304 & $\begin{array}{l}\mathrm{E} 103^{\circ} 37^{\prime} 02^{\prime \prime} \\
\mathrm{N} 39^{\circ} 01^{\prime} 45^{\prime \prime}\end{array}$ & $\begin{array}{c}\text { Lycium ruthenicum, Halogeton } \\
\text { arachnoideus, } P \text {. nigellastrum, } \\
\text { Limoniumau-reum } \\
\end{array}$ & $\begin{array}{c}\text { Atriplex sibirica, Salsola ikonnikovii, } \\
\text { Lepidium lotifolium, Echinopilon } \\
\text { divaricatum et al. }\end{array}$ & The autumn crops \\
\hline $24 \mathrm{a}$ & 1306 & $\begin{array}{l}\mathrm{E} 103^{\circ} 36^{\prime} 24^{\prime \prime} \\
\mathrm{N} 39^{\circ} 02^{\prime} 34^{\prime \prime}\end{array}$ & $\begin{array}{c}\text { Lycium ruthenicum, Kalidium } \\
\text { foliatum, Reaumuria songarica, } \\
\text { Phragmites australis } \\
\end{array}$ & $\begin{array}{l}\text { Halogeton arachnoideus, Nitraria } \\
\text { schoberi, } P . \text { nigellastrum, Eragrostis } \\
\text { pilosa } \text { et al. }\end{array}$ & The autumn crops \\
\hline $31 \mathrm{a}$ & 1306 & $\begin{array}{l}\mathrm{E} 103^{\circ} 36^{\prime} 13^{\prime \prime} \\
\mathrm{N} 39^{\circ} 02^{\prime} 34^{\prime \prime}\end{array}$ & $\begin{array}{c}\text { Lycium ruthenicum, Kalidium } \\
\text { foliatum, Reaumuria songarica, } P . \\
\text { nigellastrum }\end{array}$ & $\begin{array}{c}\text { Nitraria schoberi, Scorzonera } \\
\text { hispanica, Halogeton arachnoideus, } \\
\text { Peganum harmala et al. }\end{array}$ & The autumn crops \\
\hline
\end{tabular}

Five soil sample collection points were selected in each site using "S" method, and each collection point was repeated three times. $0 \sim 10 \mathrm{~cm}$ soil samples were taken with soil drill (soil drills type: SoilMoisture0200.0206L06.0215F1L05). After the same soil samples were uniformly mixed, the soil samples were separated into two parts by quartering and enclosed to be brought back to the laboratory. One part is used for the determination of soil physicochemical properties, and the other part is used for the determination of soil biological properties (at $4^{\circ} \mathrm{C}$ for less than $24 \mathrm{~h}$ ).

\section{Determination method}

\section{Determination of soil physicochemical properties}

Soil $\mathrm{pH}$ was determined by $\mathrm{pH}$ instrument (PHS-3S), soil moisture content was measured by oven drying method in incubator (Shanghai yiheng DHG-9030A electric thermostat), and the sand content (the sum of coarse sand and fine sand) was measured by Malvern Mastersizer 2000. The organic carbon was determined by potassium dichromate-sulfuric acid external heating method, total nitrogen was determined by Kjeldahl distillation method, total phosphorus, available phosphorus were determined by $\mathrm{NaHCO} 3$ extraction- Mo-Sb-Vc colorimetric method, total potassium, available 
potassium were determined by atomic absorption spectrophotometry. Refer to "Soil Agricultural Chemistry Analysis" for the specific methods (Bao, 2005).

\section{Determination of soil microbial properties}

(1) The amount of soil bacteria, fungi and actinomycetes was determined by flat surface smearing (Xu and Zheng, 1986), in which beef extract peptone medium was used for bacteria, Martin-Bengal red medium was used for fungus, and modified Gaoshi No.1 medium was used for actinomycete.

(2) Determination of soil microbial biomass

Soil microbial biomass was determined by chloroform fumigation incubation method (Sparling et al., 1997; Yao and Huang, 2006).

1) Soil microbial biomass carbon (SMBC): was determined by $\mathrm{K} 2 \mathrm{Cr} 2 \mathrm{O} 7-\mathrm{H} 2 \mathrm{SO} 4$ external heating method. The calculation formula is:

$$
\mathrm{SMBC}(\mathrm{mg} / \mathrm{kg})=(\mathrm{Ec}-\mathrm{Ec} 0) / \mathrm{kEc}
$$

2) Soil microbial biomass nitrogen $(\mathrm{SMBN})$ : was determined by Kjeldahl determination method. The calculation formula is:

$$
\operatorname{SMBN}(\mathrm{mg} / \mathrm{kg})=(\mathrm{En}-\mathrm{En} 0) / \mathrm{kEn}
$$

3) Soil microbial biomass phosphorus (SMBP): was determined by molybdenum blue colorimetric method. The calculation formula is:

$$
\operatorname{SMBP}(\mathrm{mg} / \mathrm{kg})=(\mathrm{Ep}-\mathrm{Ep} 0) / \mathrm{kEp}
$$

In the formula: Ec, En and Ep are the contents of organic carbon, total nitrogen and phosphorus in the fumigated soil extract, Ec0, En0 and Ep0 are the contents of organic carbon, total nitrogen and phosphorus in the unfumigation soil extract, and kEc, kEn and $\mathrm{kEp}$ are correction coefficients which are $0.38,0.54$ and 0.40 , respectively.

\section{Data Analysis and Processing}

The test data was the average of 3 replications, and analysis of variance, correlation analysis, and principal components analysis (PCA) were performed using SPSS 19.0 software and tabulated with Excel 2010.

\section{Results and analysis}

\section{Characteristics of physic-chemical properties of soil}

The soil physicochemical properties of secondary grassland with different abandoned years are shown in Table 2. With the extension of abandoned years, soil $\mathrm{pH}$ generally shows an upward trend with a range of 8.0-8.5; the soil water content decreases first in 1-4a, 8- 24a and then increases in 4-8a, 24-31a, with significant difference between different years $(\mathrm{P}<0.05)$, of which the maximum is reached at $8 \mathrm{a}(7.26 \%)$; the sand content in the soil decreases first in 1-4a, 5- 8a, 15-24a and then increases in 4-5a, 8-15a, 24-31a, with significant difference between different years $(\mathrm{P}<0.05)$.

With the extension of abandoned years, soil organic carbon increases first in 1-2a, 3$4 a, 5-15 a, 24-31 a$ and then decreases in 2-3a, 4-5a, 15-24a, with maximum of $1.76 \%$ 
achieved at $4 \mathrm{a}$; the total nitrogen increases first in 1-2a and 3-4a, then decreases (2-3a) and finally stabilizes (4-31a), with the maximum of 0.07 achieved at $1 \mathrm{a}$, $4 \mathrm{a}$; the total phosphorus decreases first in 1-3a, 4-5a, 8-15a, 24-31a and then increases in 3-4a, 5-8a, $15-24 \mathrm{a}$, with significant difference between different abandoned years $(\mathrm{P}<0.05)$, and the maximum of $0.66 \mathrm{~g} / \mathrm{kg}$ is achieved at $1 \mathrm{a}$, followed by $4 \mathrm{a}(0.58 \mathrm{~g} / \mathrm{kg})$; the total potassium increases first in 1-2a, 4-5a, 15-24a and then decreases in 2-4a, 5-15a, 24-31a, with the maximum of $38.17 \mathrm{~g} / \mathrm{kg}$ achieved at $5 \mathrm{a}$. The available potassium increases first in $1-3 \mathrm{a}$, 4a-15a, 24-31a and then decreases in 3-4a, 15-24a, with the maximum of $636.09 \mathrm{mg} / \mathrm{kg}$ achieved at $15 \mathrm{a}$, showing significant difference between different years $(\mathrm{P}<0.05)$; the available phosphorus decreases first in 1-2a, 3-5a, 15-24a and then increases in 2- 3a, 515a, 24-31a, with the maximum of $0.178 \mathrm{mg} / \mathrm{kg}$ achieved at $3 \mathrm{a}$, showing no significant difference between different abandoned years $(\mathrm{P}>0.05)$.

\section{Soil microbial properties}

As can be seen from Table 3, the number of soil bacteria decreases sharply (1-2a) with the extension of abandoned years, increasing first after 2a (2-4a, 8-24a) and then decreasing (4-8a, 24- 31a); the number of fungi decreases first (1-2a, 4-5a, 8-31a) and then increases $(2-4 a, 5-8 a)$; the number of actinomycetes decreases first (1-3a, 4-5a, 815a, 24-31a) and then increases (3-4a, 5-8a, 15-24a), reaching the maximum of $8.37 \times 105 \mathrm{cfu} / \mathrm{g}$ at $8 \mathrm{a}$ and showing significant difference between different abandoned years $(\mathrm{P}<0.05)$; soil microbes have different compositions, and with the extension of abandoned years, the proportion of bacteria, fungi and actinomycetes decreases to a different extent, of which bacteria accounts for the largest proportion, with the maximum of $95.65 \%$ achieved at $1 \mathrm{a}$, while the proportion of fungi is less than $1 \%$.

With the extension of abandoned years, SMBC fluctuates, increasing first (1-2a, 3-8a, 15-24a) and then decreasing (2-3a, 8-15a, 24-31a), showing significant difference between different abandoned years $(\mathrm{P}<0.05)$, with the maximum of $979.13 \mathrm{mg} / \mathrm{kg}$ achieved at $8 \mathrm{a}$; SMBN decreases first $(1-2 \mathrm{a}, 4-8 \mathrm{a}, 15-24 \mathrm{a})$ and then increases $(2-4 \mathrm{a}, 8-$ 15a, 24-31a); SMBP increases first (1-2a, 3-4a) and then decreases (2-3a, 4-31a), reaching the maximum of $168.35 \mathrm{mg} / \mathrm{kg}$ at $4 \mathrm{a}$; SMBC/SMBN increases first (1-2a, 3-8a, $15-24 a)$ and then decreases $(2-3 a, 8-15 a, 24-31 a)$, reaching the maximum of 9.2 at $8 a$.

\section{Correlation between soil microbial properties and soil physic-chemical properties}

From Table 4, it can be known that the number of soil bacteria is significantly positively correlated with total phosphorus $(\mathrm{P}<0.01)$, and significantly negatively correlated with $\mathrm{pH}$, total potassium and available potassium $(\mathrm{P}<0.01)$. The number of fungi is significantly positively correlated with organic carbon and total nitrogen $(\mathrm{P}<0.01)$, significantly negatively correlated with available potassium $(\mathrm{P}<0.01)$, and negatively correlated with water content $(\mathrm{P}<0.05)$. The number of actinomycetes is significantly negatively correlated with sand $(\mathrm{P}<0.01)$, and positively correlated with organic carbon $(\mathrm{P}<0.05)$; SMBC is significantly positively correlated with $\mathrm{pH}(\mathrm{P}<0.01)$, positively correlated with available potassium $(\mathrm{P}<0.05)$, and negatively correlated with sand and available phosphorus $(\mathrm{P}<0.05)$. SMBN is significantly positively correlated with organic carbon $(\mathrm{P}<0.01)$, significantly negatively correlated with water content and available potassium $(\mathrm{P}<0.01)$, and positively correlated with total nitrogen $(\mathrm{P}<0.05)$. SMBP is significantly positively correlated with organic carbon $(\mathrm{P}<0.01)$, and positively correlated with total nitrogen $(\mathrm{P}<0.05)$. The correlation between the remaining is not obvious. 
Table 2. Soil physic-chemical properties under different abandoned years

\begin{tabular}{c|c|c|c|c|c|c|c|c|c}
\hline \multirow{2}{*}{ Index } & \multicolumn{9}{c}{ Abandoned years (a) } \\
\cline { 2 - 8 } & $\mathbf{1}$ & $\mathbf{2}$ & $\mathbf{3}$ & $\mathbf{4}$ & $\mathbf{5}$ & $\mathbf{8}$ & $\mathbf{1 5}$ & $\mathbf{2 4}$ & $\mathbf{3 1}$ \\
\hline $\mathrm{pH}$ & $8 \pm 0.06 \mathrm{f}$ & $8.09 \pm 0.04 \mathrm{ef}$ & $8.18 \pm 0.05 \mathrm{de}$ & $8.24 \pm 0.04 \mathrm{~cd}$ & $8.27 \pm 0.02 \mathrm{bcd}$ & $8.32 \pm 0.01 \mathrm{bc}$ & $8.38 \pm 0.04 \mathrm{ab}$ & $8.45 \pm 0.04 \mathrm{a}$ & $8.5 \pm 0.02 \mathrm{a}$ \\
Water content & $5.85 \pm 0.121 \mathrm{~b}$ & $5.66 \pm 0.123 \mathrm{~b}$ & $2.89 \pm 0.156 \mathrm{~d}$ & $1.32 \pm 0.038 \mathrm{e}$ & $2.92 \pm 0.048 \mathrm{ad}$ & $7.26 \pm 0.047 \mathrm{a}$ & $3.90 \pm 0.286 \mathrm{c}$ & $1.63 \pm 0.020 \mathrm{e}$ & $3.27 \pm 0.239 \mathrm{~d}$ \\
Sand content $\%$ & $60.15 \pm 0.19 \mathrm{c}$ & $55.51 \pm 0.13 \mathrm{de}$ & $54.87 \pm 0.08 \mathrm{ef}$ & $54.54 \pm 0.12 \mathrm{ef}$ & $65.63 \pm 0.15 \mathrm{a}$ & $54.11 \pm 0.55 \mathrm{f}$ & $62.45 \pm 0.02 \mathrm{~b}$ & $53.67 \pm 0.92 \mathrm{f}$ & $56.38 \pm 0.07 \mathrm{~d}$ \\
Organic carbon/\% & $1.02 \pm 0.009 \mathrm{c}$ & $1.1 \pm 0.012 \mathrm{~b}$ & $0.95 \pm 0.46 \mathrm{c}$ & $1.76 \pm 0.046 \mathrm{a}$ & $0.73 \pm 0.011 \mathrm{e}$ & $0.99 \pm 0.008 \mathrm{c}$ & $1.12 \pm 0.013 \mathrm{~b}$ & $0.75 \pm 0.013 \mathrm{e}$ & $0.87 \pm 0.015 \mathrm{~d}$ \\
Total nitrogen/\% & $0.05 \pm 0.008 \mathrm{~b}$ & $0.07 \pm 0.004 \mathrm{a}$ & $0.03 \pm 0.003 \mathrm{c}$ & $0.07 \pm 0.006 \mathrm{a}$ & $0.03 \pm 0.002 \mathrm{c}$ & $0.03 \pm 0.002 \mathrm{c}$ & $0.03 \pm 0.002 \mathrm{c}$ & $0.03 \pm 0.003 \mathrm{c}$ & $0.03 \pm 0.002 \mathrm{c}$ \\
Total phosphorus $(\mathrm{g} / \mathrm{kg})$ & $0.66 \pm 0.002 \mathrm{a}$ & $0.57 \pm 0.004 \mathrm{~b}$ & $0.54 \pm 0.008 \mathrm{~d}$ & $0.58 \pm 0.006 \mathrm{~b}$ & $0.45 \pm 0.003 \mathrm{f}$ & $0.57 \pm 0.006 \mathrm{~b}$ & $0.38 \pm 0.005 \mathrm{~g}$ & $0.55 \pm 0.001 \mathrm{c}$ & $0.51 \pm 0.005 \mathrm{e}$ \\
Total potassium $(\mathrm{g} / \mathrm{kg})$ & $34.57 \pm 0.05 \mathrm{e}$ & $37.18 \pm 0.40 \mathrm{~b}$ & $36.54 \pm 0.25 \mathrm{bc}$ & $35.60 \pm 0.19 \mathrm{~cd}$ & $38.17 \pm 0.19 \mathrm{a}$ & $36.23 \pm 0.24 \mathrm{bc}$ & $34.99 \pm 0.48 \mathrm{de}$ & $37.02 \pm 0.49 \mathrm{~b}$ & $36.60 \pm 0.28 \mathrm{bc}$ \\
Quick-available K $(\mathrm{mg} / \mathrm{kg})$ & $266.26 \pm 17.07 \mathrm{~d}$ & $357.54 \pm 5.75 \mathrm{c}$ & $383.56 \pm 2.94 \mathrm{c}$ & $277.86 \pm 9.29 \mathrm{~d}$ & $380.22 \pm 54.61 \mathrm{c}$ & $479.97 \pm 6.46 \mathrm{~b}$ & $636.09 \pm 11.43 \mathrm{a}$ & $520.63 \pm 13.83 \mathrm{~b}$ & $529.94 \pm 1.33 \mathrm{~b}$ \\
Quick-available P $(\mathrm{mg} / \mathrm{kg})$ & $0.177 \pm 0.053 \mathrm{a}$ & $0.159 \pm 0.035 \mathrm{ab}$ & $0.178 \pm 0.12 \mathrm{a}$ & $0.115 \pm 0.064 \mathrm{~cd}$ & $0.106 \pm 0.30 \mathrm{~d}$ & $0.132 \pm 0.05 \mathrm{bcd}$ & $0.150 \pm 0.001 \mathrm{abc}$ & $0.106 \pm 0.18 \mathrm{~d}$ & $0.134 \pm 0.092 \mathrm{bcd}$ \\
\hline
\end{tabular}

The different lowercase letters in the same line indicate different years abandoned cultivated lands have significant different at 0.05 level, the same below

Table 3. The number of soil microbe under different abandoned years

\begin{tabular}{|c|c|c|c|c|c|c|c|c|c|}
\hline \multirow{2}{*}{ Index } & \multicolumn{9}{|c|}{ Abandoned years (a) } \\
\hline & 1 & 2 & 3 & 4 & 5 & 8 & 15 & 24 & 31 \\
\hline Bacteria/ $\left(\times 10^{5} \mathrm{cfu} / \mathrm{g}\right)$ & $23.06 \pm 0.299 \mathrm{a}$ & $2.22 \pm 0.173 \mathrm{c}$ & $2.68 \pm 0.067 \mathrm{c}$ & $7.30 \pm 0.232 b$ & $1.11 \pm 0.067 \mathrm{de}$ & $0.45 \pm 0.063 \mathrm{e}$ & $1.37 \pm 0.113 \mathrm{~d}$ & $7.71 \pm 0.616 \mathrm{~b}$ & $0.45 \pm 0.063 \mathrm{e}$ \\
\hline Fungi/ $\left(\times 10^{3} \mathrm{cfu} / \mathrm{g}\right)$ & $0.72 \pm 0.063 \mathrm{de}$ & $0.52 \pm 0.067 \mathrm{ef}$ & $2.16 \pm 0.113 b$ & $4.65 \pm 0.110 \mathrm{a}$ & $0.72 \pm 0.067 \mathrm{de}$ & $1.10 \pm 0.067 \mathrm{c}$ & $0.91 \pm 0.067 \mathrm{~cd}$ & $0.45 \pm 0.063 \mathrm{f}$ & $0.45 \pm 0.063 \mathrm{f}$ \\
\hline Actinomycetes/ $\left(\times 10^{5} \mathrm{cfu} / \mathrm{g}\right)$ & $1.04 \pm 0.063 \mathrm{de}$ & $0.46 \pm 0.067 \mathrm{f}$ & $0.46 \pm 0.067 \mathrm{f}$ & $7.69 \pm 0.282 b$ & $0.59 \pm 0.000 \mathrm{ef}$ & $8.37 \pm 0.299 \mathrm{a}$ & $1.43 \pm 0.063 \mathrm{~d}$ & $3.63 \pm 0.234 \mathrm{c}$ & $0.97 \pm 0.110 \mathrm{def}$ \\
\hline Percentage of bacteria $/ \%$ & $95.65 \pm 0.002 \mathrm{a}$ & $82.9 \pm 0.01 \mathrm{~b}$ & $84.92 \pm 0.02 b$ & $48.56 \pm 0.004 d$ & $65 \pm 0.01 \mathrm{c}$ & $5.13 \pm 0.006 \mathrm{f}$ & $48.57 \pm 0.03 \mathrm{~d}$ & $67.89 \pm 0.01 \mathrm{c}$ & $31.84 \pm 0.04 \mathrm{e}$ \\
\hline Percentage of fungi/\% & $0.03 \pm 0.0002 \mathrm{e}$ & $0.19 \pm 0.0002 \mathrm{~d}$ & $0.69 \pm 0.0005 \mathrm{a}$ & $0.31 \pm 0.0001 \mathrm{c}$ & $0.42 \pm 0.0002 b$ & $0.12 \pm 0.00003 \mathrm{~d}$ & $0.32 \pm 0.0002 \mathrm{c}$ & $0.04 \pm 0.00003 \mathrm{e}$ & $0.32 \pm 0.0004 \mathrm{c}$ \\
\hline Percentage of actinomycetes $/ \%$ & $4.32 \pm 0.002 \mathrm{f}$ & $16.9 \pm 0.01 \mathrm{e}$ & $14.39 \pm 0.02 \mathrm{e}$ & $51.13 \pm 0.003 \mathrm{c}$ & $34.58 \pm 0.01 \mathrm{~d}$ & $94.75 \pm 0.006 \mathrm{a}$ & $51.1 \pm 0.03 \mathrm{c}$ & $32.07 \pm 0.01 \mathrm{~d}$ & $67.84 \pm 0.04 \mathrm{~b}$ \\
\hline $\mathrm{SMBC}(\mathrm{mg} / \mathrm{kg})$ & $437.40 \pm 8.245 \mathrm{de}$ & $523.13 \pm 13.08 \mathrm{c}$ & $257.91 \pm 13.542 \mathrm{f}$ & $417.86 \pm 5.158 \mathrm{e}$ & $469.75 \pm 5.065 \mathrm{~d}$ & $979.13 \pm 13.536 \mathrm{a}$ & $433.27 \pm 8.842 \mathrm{e}$ & $959.48 \pm 13.154 \mathrm{a}$ & $773.17 \pm 13.105 b$ \\
\hline SMBN $(\mathrm{mg} / \mathrm{kg})$ & $154.45 \pm 1.352 \mathrm{c}$ & $108.98 \pm 0.954 \mathrm{e}$ & $169.59 \pm 1.484 b$ & $215.50 \pm 1.885 \mathrm{a}$ & $153.84 \pm 1.346 \mathrm{c}$ & $106.42 \pm 0.930 \mathrm{e}$ & $122.65 \pm 1.073 d$ & $121.64 \pm 1.063 \mathrm{~d}$ & $124.32 \pm 1.089 \mathrm{~d}$ \\
\hline SMBP $(\mathrm{mg} / \mathrm{kg})$ & $105.89 \pm 0.813 \mathrm{f}$ & $125.88 \pm 0.813 \mathrm{~d}$ & $122.64 \pm 0.813 \mathrm{e}$ & $168.35 \pm 0.814 \mathrm{a}$ & $148.14 \pm 0.814 b$ & $133.65 \pm 0.815 \mathrm{c}$ & $126.73 \pm 0.814 \mathrm{~d}$ & $102.81 \pm 0.814 \mathrm{~g}$ & $92.92 \pm 0.813 \mathrm{~h}$ \\
\hline SMBC/SMBN & $2.83 \pm 0.08 \mathrm{f}$ & $4.8 \pm 0.12 \mathrm{~d}$ & $1.52 \pm 0.08 \mathrm{~h}$ & $1.94 \pm 0.02 \mathrm{~g}$ & $3.05 \pm 0.03 \mathrm{f}$ & $9.2 \pm 0.16 \mathrm{a}$ & $3.53 \pm 0.08 \mathrm{e}$ & $7.89 \pm 0.13 b$ & $6.22 \pm 0.12 \mathrm{c}$ \\
\hline
\end{tabular}


Table 4. Correlation analysis between soil microbial properties and Soil physic-chemical properties

\begin{tabular}{c|c|c|c|c|c|c}
\hline Index & Bacteria & Fungi & Actinomycetes & SMBC & SMBN & SMBP \\
\hline $\mathrm{pH}$ & $-0.536^{* *}$ & -0.145 & 0.188 & $0.541^{* *}$ & -0.274 & -0.204 \\
Water content & 0.104 & $-0.435^{*}$ & 0.045 & 0.2 & $-0.572^{* *}$ & -0.182 \\
Sand content & 0.048 & -0.031 & $-0.491^{* *}$ & $-0.407^{*}$ & 0.021 & 0.139 \\
Organic carbon & 0.124 & $0.816^{* *}$ & $0.475^{*}$ & -0.372 & $0.573^{* *}$ & $0.620^{* *}$ \\
Total nitrogen & 0.345 & $0.531^{* *}$ & 0.256 & -0.320 & $0.430^{*}$ & $0.438^{*}$ \\
Total phosphorus & $0.666^{* *}$ & 0.181 & 0.288 & 0.133 & 0.190 & -0.125 \\
Total potassium & $-0.535^{* *}$ & -0.241 & -0.185 & 0.198 & -0.189 & 0.076 \\
Quick-available K & $-0.538^{* *}$ & $-0.443^{* *}$ & -0.057 & $0.442^{*}$ & $-0.609 * *$ & -0.372 \\
Available P & 0.275 & -0.097 & -0.380 & $-0.435^{*}$ & -0.056 & -0.283 \\
\hline
\end{tabular}

**: indicate very significant correlation $(P<0.01)$; *: indicate significant correlation $(P<0.05)$

\section{Comprehensive evaluation of soil fertility quality}

Soil quality assessment can provide a theoretical basis for the restoration and management of degraded land (Kirkegaard et al., 2000). In this study, principal component analysis was used to comprehensively evaluate soil quality (Table 5). The cumulative contribution rate of the first 5 principal components is $87.61 \%$, which is in line with the requirements of principal component analysis. Therefore, the 5 principal component analysis can represent the variation information of soil quality of secondary lands with different abandoned years in the lower reaches of Shiyang River.

Table 5. The loading factor, eigenvalue and contribution ratio of 5 PCAs

\begin{tabular}{c|c|c|c|c|c}
\hline Index & $\begin{array}{c}\text { The first } \\
\text { principal } \\
\text { component }\end{array}$ & $\begin{array}{c}\text { The second } \\
\text { principal } \\
\text { component }\end{array}$ & $\begin{array}{c}\text { The third } \\
\text { principal } \\
\text { component }\end{array}$ & $\begin{array}{c}\text { The forth } \\
\text { principal } \\
\text { component }\end{array}$ & $\begin{array}{c}\text { The fifth } \\
\text { principal } \\
\text { component }\end{array}$ \\
\hline pH & -0.634 & 0.614 & 0.179 & 0.184 & -0.270 \\
Water content & -0.100 & -0.630 & 0.329 & 0.168 & 0.621 \\
Sand content & -0.199 & -0.117 & -0.770 & 0.011 & 0.150 \\
Organic carbon & 0.812 & 0.291 & 0.098 & 0.340 & 0.152 \\
Total nitrogen & 0.824 & -0.079 & 0.171 & -0.138 & 0.224 \\
Total phosphorus & 0.558 & -0.458 & 0.586 & -0.293 & -0.171 \\
Total potassium & -0.381 & 0.293 & -0.139 & -0.757 & 0.241 \\
Quick-available K & -0.810 & 0.252 & 0.052 & 0.469 & -0.014 \\
Available P & 0.164 & -0.692 & -0.166 & 0.375 & 0.091 \\
Bacteria & 0.480 & -0.596 & 0.091 & -0.031 & -0.473 \\
Fungi & 0.802 & 0.530 & -0.005 & 0.155 & -0.076 \\
Actinomycetes & 0.332 & 0.506 & 0.682 & 0.147 & 0.147 \\
Soil microbial C & -0.537 & 0.145 & 0.785 & -0.139 & -0.022 \\
Soil microbial N & 0.783 & 0.325 & -0.330 & -0.055 & -0.340 \\
Soil microbial P & 0.582 & 0.574 & -0.212 & -0.041 & 0.458 \\
Eigenvalue & 5.154 & 3.065 & 2.408 & 1.287 & 1.227 \\
Rate of variance \% & 34.361 & 20.433 & 16.051 & 8.578 & 8.179 \\
Cumulative rate \% & 34.361 & 54.794 & 70.845 & 79.423 & 87.603 \\
\hline
\end{tabular}

The first principal component mainly reflects $\mathrm{pH}$, organic matter, total nitrogen, available potassium, fungi and soil microbial biomass nitrogen index (absolute value of load value $>0.6$ ), indicating that it is the most important impact factor in soil quality assessment. The second principal component mainly reflects $\mathrm{pH}$, water content and 
bacteria. The third principal component mainly reflects sand content, actinomycetes and soil microbial biomass carbon. The fourth principal component mainly reflects total potassium, and the fifth principal component mainly reflects water content.

From weighting of the eigenvectors and the normalized data, the scores of the 5 common factors in different abandoned years are obtained, and then comprehensive scores of soil fertility quality under different abandoned years are obtained by weighting of scores of the factors and the variance contribution rate (soil quality comprehensive evaluation index). See Table 6 for the result, which is sorted as abandoned year 4a $(1.087)>$ abandoned year $8 \mathrm{a}(0.333)>$ abandoned year $2 \mathrm{a}(0.007)>$ abandoned year $3 \mathrm{a}$ $(-0.087)>$ abandoned year 15a $(-0.157)>$ abandoned year $1 \mathrm{a}(-0.183)>$ abandoned year $24 \mathrm{a}(-0.253)>$ abandoned year $31 \mathrm{a}(-0.363)>$ abandoned year $5 \mathrm{a}(-0.383)$, indicating that abandoned year $4 \mathrm{a}$ is a key period of restoration. After abandoned year 5a, soil quality decreased to varying degrees. It can be seen that the sorting results of soil quality comprehensive evaluation index are consistent with the previous demonstration results, so the results of principal component analysis can better reflect the actual conditions of the soil.

Table 6. General sores and ranking under different managements

\begin{tabular}{c|ccccc|c|c}
\hline $\begin{array}{c}\text { Abandoned } \\
\text { years(a) }\end{array}$ & \multicolumn{5}{|c|}{ Factor score } & \multirow{2}{*}{$\begin{array}{c}\text { General } \\
\text { sores }\end{array}$} & Ranking \\
\cline { 2 - 7 } & Factor1 & Factor2 & Factor3 & Factor4 & Factor5 & -0.183 & 6 \\
2 & 0.917 & -2.150 & -0.009 & 0.100 & -0.806 & -0.007 & 3 \\
3 & 0.244 & -0.811 & 0.166 & -0.694 & 1.488 & 0.007 \\
4 & 0.347 & -0.227 & -0.801 & 0.041 & -0.417 & -0.087 & 4 \\
5 & 2.136 & 1.584 & 0.243 & 0.211 & -0.310 & 1.087 & 1 \\
8 & -0.494 & 0.591 & -1.594 & -1.489 & 0.604 & -0.383 & 9 \\
15 & -0.389 & 0.171 & 1.771 & 0.351 & 1.424 & 0.333 & 2 \\
24 & -0.748 & 0.289 & -1.041 & 2.118 & 0.313 & -0.157 & 5 \\
31 & -0.916 & 0.425 & 1.009 & -0.782 & -1.471 & -0.253 & 7 \\
\hline
\end{tabular}

\section{Discussion}

The experimental study found that with the extension of abandoned years, soil $\mathrm{pH}$ of the secondary grassland with different abandoned years in the lower reaches of Shiyang River gradually increased but did not show significant difference, which was generally alkaline. Soil available potassium content increased in fluctuations, which may be because soil leaching effect increased the available potassium content in the soil surface (Wang, 2016); the soil water content was generally "V"-shaped, and the maximum value appeared at abandoned year 8a, which may be due to the decline of vegetation coverage and surface exposure with the return of farmland to forest (Wang, 2016). In addition, because of the combined effect of precipitation and natural sedimentation, the soil structure is continuously restored, and the soil capillary water is effectively stored (Wang, 2016). Moreover, as abandoned year 8a vegetation is mainly perennial shrubs, such plants can obtain water in deeper soil layers, while surface soil water content contributes little to it (Walter, 1979); soil sand content decreased gradually during abandoned years 1-4a, fluctuated after 5a, and gradually increased after abandoned year 24a. Soil organic carbon, total nitrogen, total phosphorus, total potassium and available phosphorus decreased with the extension of abandoned years. The reason for this change may be that the vegetation richness index and diversity index decreased in 
varying degrees with the extension of abandoned years, and then the bare soil area increased gradually. In addition, the lower reaches of Shiyang River has strong wind (Chang et al., 2007), desertification and wind erosion of the sample site thus deteriorate, while soil sand is not easily eroded by wind, causing a large loss of nutrients. Due to the limitation of water and heat, the slow decomposition rate of organic matter reduces the ability of nutrient return (Liu et al., 2016). At the same time, with the extension of abandoned years, vegetation coverage and biomass decrease, which reduces the supplement of soil nutrients by plant residue (Li et al., 2010).

Bacteria in the soil constitute the main microbial group, its maximum number is up to $23.06 \times 105 \mathrm{cfu} / \mathrm{g}$, accounting for $95.65 \%$ followed by actinomycetes and fungi was the least. This may be because the soil in this study area is slightly alkaline, which is beneficial to the growth of bacteria and actinomycetes, while fungus grows poorly in a slightly alkaline environment. This is consistent with the results of Tan Qiujin (Tan et al., 2014). The number of soil bacteria, fungi and actinomycetes in different abandoned years reaches the highest at abandoned year $1 \mathrm{a}$, abandoned year $4 \mathrm{a}$ and abandoned year 8a. During abandoned years 1-8a, field husbandry, fertilization and other agricultural management measures just stopped or stopped for a short time, so the good soil moisture conditions and ventilation, coupled with higher soil nutrient content enabled strong microbial activity. In addition, an increase in the number of soil microbes leads to a corresponding increase in the proportion. With the extension of abandoned years, the trend of soil microbial biomass changed slightly. SMBC content was the highest at abandoned year $8 \mathrm{a}$, SMBN and SMBP contents were the highest at abandoned year $4 \mathrm{a}$, which was significantly higher than that at other abandoned years $(\mathrm{P}<0.05)$. This may be because vegetation grew fast at abandoned years $4 \mathrm{a}$ and $8 \mathrm{a}$, root biomass and root exudates then increased, so that soil nutrients accumulated continuously. It was also related to the fact that the collected sample was surface soil $(0 \sim 10 \mathrm{~cm})$. The surface layer accumulated a large number of plant residues which enriched soil organic matter, and also the layer had good hydrothermal and ventilation condition (Wen et al., 2010), providing a suitable environment for microbial growth and reproduction, and promoting biological activity of microbes. The soil microbial biomass carbon and nitrogen ratio are important indicators to characterize whether soil microbial growth is restricted by carbon or nitrogen, which affect the community structure of soil microbes (Yang et al., 2014). Soil $\mathrm{SMBC} / \mathrm{SMBN} \geq 30$ and $\mathrm{SMBC} / \mathrm{SMBN} \leq 20$ indicate that soil microbial growth is respectively limited by nitrogen source and carbon source. When $\mathrm{SMBC} / \mathrm{SMBN}=25$, it is most beneficial to soil microbial growth, which is conducive to the normal function of soil microbes in ecosystem (Zhang et al., 2012). SMBC/SMBN ranged from 1.5 9.2 in the secondary grassland with different abandoned years in the lower reaches of Shiyang River, indicating that supply quantity of carbon source is the main limiting factor for soil microbial growth. The correlation results also show that soil microbial biomass is related to soil nutrients in different degrees (Niu et al., 2011), which is significantly correlated with soil organic matter, so this conclusion is further confirmed. However, soil represents a relatively complex ecosystem, and soil microbial biomass is also affected by factors such as temperature, air temperature, soil bulk density, etc. which demands comprehensive considerations.

Soil microbes are reservoirs of soil nutrients and play an important role in soil organic matter and nutrient conversion and cycling (Singh et al., 2014). Wang et al. (2010) and Yang et al. (2014) have found that there is a certain correlation between soil microbes and soil physicochemical properties. This study also shows that soil microbial 
quantity, soil microbial biomass under different abandoned years are closely related to soil physicochemical properties, good physical environment (moisture, $\mathrm{pH}$ and gas permeability) will promote the growth of soil bacteria, fungi and actinomycetes, thereby increasing the number of microbes, and the change in soil microbial quantity will accelerate the soil nutrient cycle, leading to an increase in soil nutrients (Taylor et al., 2002). The principal component analysis showed that indicators such as soil $\mathrm{pH}$, sand, water content, organic matter, total nitrogen, available potassium, fungi, soil microbial biomass carbon, soil microbial biomass nitrogen have a large contribution rate in each principal component, which can be used to evaluate important factors in soil fertility quality of the area. The results of comprehensive evaluation of soil fertility indicated that abandoned year $4 a>$ abandoned year $8 a>$ abandoned year $2 a>$ abandoned year $3 a>$ abandoned year $15 a>$ abandoned year $1 a>$ abandoned year $24 a>$ abandoned year $31 \mathrm{a}>$ abandoned year $5 \mathrm{a}$, of which abandoned year $4 \mathrm{a}$ is a key period of recovery. This conclusion is consistent with the conclusions obtained from single factor analysis to a certain extent and the two are mutually confirmed.

\section{Conclusion}

With the extension of abandoned years, soil $\mathrm{pH}$ gradually increased, soil water content, sand content, bacteria number, actinomycetes number, SMBN decreased first and then increased; soil organic carbon, total potassium, available potassium, available phosphorus, SMBC, SMBP, The SMBC/SMBN increased first and then decreased; the total nitrogen first increased, then decreased, then increased and finally stabilized; the total phosphorus and fungi decreased first, then increased and finally decreased. There is a close correlation between soil physicochemical properties and soil microbial quantity and soil microbial biomass. Indicators such as soil $\mathrm{pH}$, sand, water content, organic matter, total nitrogen, available potassium, fungi, soil microbial biomass carbon and soil microbial biomass nitrogen are important factors for evaluating soil fertility quality in this area. It can be inferred from the comprehensive evaluation of soil fertility quality that the abandoned year $4 \mathrm{a}$ is the key stage of restoration and control process in Shiyang River Basin management.

Acknowledgements. This paper belongs to the project of the China National Natural Science Foundation (31760709), Gansu provincial youth science and technology fund project (18JR3RA019) and Gansu provincial forestry science and technology project $(2017 \mathrm{kj} 025)$.

\section{REFERENCES}

[1] Bao, S. D. (2005): Agrochemistry soil analysis Handbook. - Beijing: China Agricultural Press: 23-107.

[2] Chai, X. H., Wang, L. D., Yao, T. (2015): Effects of different years of cultivation abandonment on soil physical, chemical and microbial characteristics in the midstream and downstream of Shiyang river area. - Acta Prataculturae Sinica 24(8): 24-34.

[3] Chang, Z. F., Zhao, M., Liu, H. J. (2007): Study on dynamic degenerate ecological characteristic of desertification in Minqin. - Chinese Agricultural Science Bulletin 23(11): 333-338. 
[4] Chang, G. Y., Wang, L., Zhang, W. X. (2016): Perceptions of peasants in Minqin County for the water conservation polices of Shiyang river basin and their effects. - Journal of Arid Land Resources and Environment 30(2): 13-19.

[5] Feng, S. W. (1963): The evolution of drainage system of the Minqin oasis. - Journal of Geographical Science 29(3): 241-249.

[6] Harris, J. A. (2003): Measurements of the soil microbial community for estimating the success of restoration. - European Journal of Soil Science 54(4): 801-808.

[7] Hu, C. J., Guo, L. (2012): Advances in research of ecological effects of vegetation restoration. - Ecology and Environmental Sciences 21(9): 1640-1646.

[8] Kardol, P., Cornips, N. J., Van Kempen, M. M. L., Bakx-Schotman, J. M. T., van der Putten, W. H. (2007): Microbe-mediated plant-soil feedback causes historical contingency effects in plant community assembly. - Ecological Monographs 77(2): 147-162.

[9] Kirkegaard, J. A., Sarwar, M., Wong, P. T. W., Mead, A., Howe, G. N., Newell, M. (2000): Field studies on the biofumigation of take-all by Brassica break crops. - Crop and Pasture Science 51(4): 445-456.

[10] Li, Z. Y., Li, C. L., Wang, D. Z. (2010): Characteristics of vegetation succession on salinized abandoned fields in lower reaches in Shiyang river. - Acta Botanica BorealiOccidentalia Sinica 30(10): 2087-2092.

[11] Liu, X. T., Wei, Y. C., Yang, X. L., Hao, M. D., Wei, X. R. (2016): Effects of different revegetation patterns on soil organic carbon and total nitrogen in the wind-water erosion crisscross region. - Chinese Journal of Applied Ecology 27(1): 91-98.

[12] Niu, S. Q., Yang, T. T., Li, J. F., Da, W. Y., Yang, J. W. (2011): Seasonal trends of microbial functional groups in Saline-alkali soil and their relationship with soil physicochemical factors in the east Hexi corridor. - Arid Zone Research 28(2): 328-334.

[13] Singh, A. K., Bordoloi, L. J., Kumar, M., Hazarika, S., Parmar, B. (2014): Land use impact on soil quality in eastern Himalayan region of India. - Environmental Monitoring and Assessment 186(4): 2013-2024.

[14] Sparling, G. P., Pankhurst, C., Doube, B. M. (1997): Soil microbial biomass, activity and nutrient cycling as indicators of soil health. - Biological Indicators of Soil Health: 97-119.

[15] Tan, Q. J., Song, T. Q., Peng, W. X., Zeng, F., Du, H. M., Zhang, H., Fan, F. (2014): Characteristics of soil microbial populations and biomass under different ecosystems in a canyon karst region. - Acta Ecologica Sinica 34(12): 3302-3310.

[16] Taylor, J. P., Wilson, B., Mills, M. S., Burns, R. G. (2002): Comparison of numbers and enzymatic activities in surface soils and subsoils using various techniques. - Soil Biology and Biochemistry 34: 387-401.

[17] Walter, H. (1979): Vegetation of the earth: second edition Handbook. - NewYork: Springer-Verlag.

[18] Wang, C. T., Long, R. J., Wang, G. X. (2010): Relationship between plant communities, characters, soil physical and chemical properties, and soil microbiology in alpine meadows. - Acta Prataculturae Sinica 19(6): 25-34.

[19] Wang, L. D. (2016): Evolution of vegetation and soil system on secondary grassland of abandoned land area in Minqin. - Lanzhou: Gansu agricultural university.

[20] Wen, D. R. Y., Li, G., Zhang, J. N. (2010): The study of soil microbial biomass and soil enzyme activity on different grassland in Hulunbeier, Inner Mongolia. - Acta Pratacultural Sinica 19(5): 94-102.

[21] Xu, G. H., Zheng, H. Y. (1986): Soil Microbial Analysis Method of Manual Handbook. Beijing: Agricultural Press: 102-109.

[22] Yang, N., Zou, D. S., Yang, M. Y., Lin, Z. G., Song, G. T., Chen, Z. Y., Zhao, L. F. (2014): Changes of soil properties in re-vegetation stages on sloping-land with purple soils in hengyang of Hunan Province, South-central China. - Acta Ecologica Sinica 34(10): 26932701.

[23] Yao, H. Y., Huang, C. Y. (2006): Soil Microbial Ecology and Experimental TechniquesHandbook. - Beijing: Science Press. 
[24] Yuan, J. Y., Ouyang, Z. Y., Zheng, H., Xu, W. H. (2012): Effects of different grassland restoration approaches on soil properties in the southeastern Horqin sandy land, northern China. - Applied Soil Ecology (61): 34-39.

[25] Zhang, L. Q., Peng, W. X., Song, T. Q., Zou, D. S., Zeng, F. P., Song, M., Yu, Z., Liu, Y. (2012): Spatial heterogeneity of soil microbial biomass carbon, nitrogen and phosphorus in sloping farmland in a karst region on the Yunnan-Guizhou Plateau. - Acta Ecologica Sinica 32(7): 2056-2065.

[26] Zhang, Y. H., Liu, S. Z., Ji, Y. F. (2016): Spatial distribution pattern and spatial association of phragmites australis in the middle reaches of Shiyang river. - Journal of Desert Research 36(2): 342-348.

[27] Zhao, H. L., Zhou, R. L., Zhao, X. Y. (2012): Desertification mechanisms and process of soil chemical and physical properties in Hulunbeir sandy grassland, Inner Mongolia. Acta Prataculturae Sinica 21(2): 1-7. 